\title{
To Great Slave and Great Bear: P.G. Downes's Journal of Travels North from Ile à la Crosse in 1938 [Part V]
}

\author{
Edited and Introduced by R.H. COCKBURN ${ }^{1}$
}

\begin{abstract}
This is the final installment of the narrative of P.G. Downes's trip by canoe, boat, and plane from Ile à la Crosse to Great Bear and Great Slave lakes in 1938, in which he presents a detailed account of his feelings, thoughts, and experiences, as well as his observations on individual men and women, northern lore, and geographic characteristics of the region.

Key words: Ile à la Crosse, Lac La Loche, Swan Lake Portage, Clearwater River, Athabaska River, Slave River, Fort Smith, Great Slave Lake, Mackenzie River, Great Bear Lake, Eldorado, Cameron Bay, Yellowknife, Chipewyans, John Hornby, George M. Douglas, Paul ' King”' Beaulieu

RÉSUMÉ. Voici le dernier episode du récit du voyage par canoë, bateau et avion de P.G. Downes à partir de l'île à la Crosse jusqu'aux Grand Lacs de l'Ours et des Esclaves en 1938, décrivant en détail ses sentiments, ses pensées et ses expériences, ainsi que ses observations sur des hommes et des femmes particuliers, le folklore du nord et les caractéristiques géographiques de la région.

Mots clés: Île à la Crosse, lac La Loche, lac du Cygne Portage, rivière à l'Eau-Claire, rivière Athabasca, rivière des Esclaves, Fort Smith, Grand Lac des Escalves, fleuve Mackenzie, Grand Lac de l'Ours, Eldorado, baie Cameron, Yellowknife, Chipewyans, John Hornby, George M. Douglas, Paul “King"' Beaulieu

Traduit pour le journal par Maurice Guibord.
\end{abstract}

\section{September 1st Fort Resolution, N.W.T.}

Beautiful, warm, clear day, slight $E+S$ breeze. Such a magnificent day as I have not experienced for many, many weeks! We got away in the morning about 6:00 a.m. from the Con. and have run all day, 16 hours in a brilliant, hot perfectness with a light easterly, and are now at Resolution. What a lovely, perfect day to cross Great Slave Lake - one in a thousand! We kept fairly off the northeast shore and chain of islands which most of the day were a smoky low outline of infinite and strange variety as they shifted into odd, inverted mirage patterns. As the various inhabitants of the boat emerged into the daylight, one particularly striking person was immediately obvious. A very tall gentleman, with snow-white hair and moustache, tanned a leathery brown, with extraordinarily bright blue eyes under shaggy white eyebrows. A jutting chin, and beak of a nose. I recognised him immediately from a portrait painted 28 years ago - George Douglas, the hero and author of Lands Forlorn [1914], his account of his trip across Great Bear Lake to the Coppermine and the Arctic coast so many years ago [1911-12], an account which I prize among my northern books [Figs. 36, 37]. He was washing a pair of khaki pants, some underwear and socks, and had the biggest wrists and the kindliest smile of anyone I have ever met. It was not long before we were chatting, a mutual friend, Dick Finnie, being an opening wedge. I followed him about from washtub to clothesline, which he had strung away at the forward end of the forward barge, like a dog, and must have been a perfect nuisance. Our talk was of course all North. Curiously, Douglas absolutely shut up when I asked about Hornby. Earlier this summer he had been on the south shore of Slave in the Chi-chi lake country, prospecting. He must have been a very powerful man - a very larged-boned man today but somewhat stooped with age, though very light on his feet and extremely active. He had one rig that was especially practical and neat. He had all his maps in small notebook-size photostatted reductions, and in sections, with descriptive notes alongside each. A news flash of the moment from the skipper: N.T. has been taken over. MacKinnon of the King has sunk another barge, making 4 his total for the last two seasons. The new manager (HBC Mackenzie River Transport), Chesshire, is out and a chap named [D.] Hutchinson is in from the States. All day Douglas has been climbing about, training his glasses on the islands, identifying this one and that with all the zest of a youngster. Talked with, or rather had my ears talked off by, a young, pleasant-voiced chap [Larry Alexander] who is editor of the Yellowknife "newspaper," a tidy little mimeographed sheet. Circulation has been as many as 800 copies and it has been sent everywhere. Facts on Yellowknife. One doctor, resident at the Con. $50 \%$ of residents typhoid innoculated. But one eating place boils its water. Total lack of

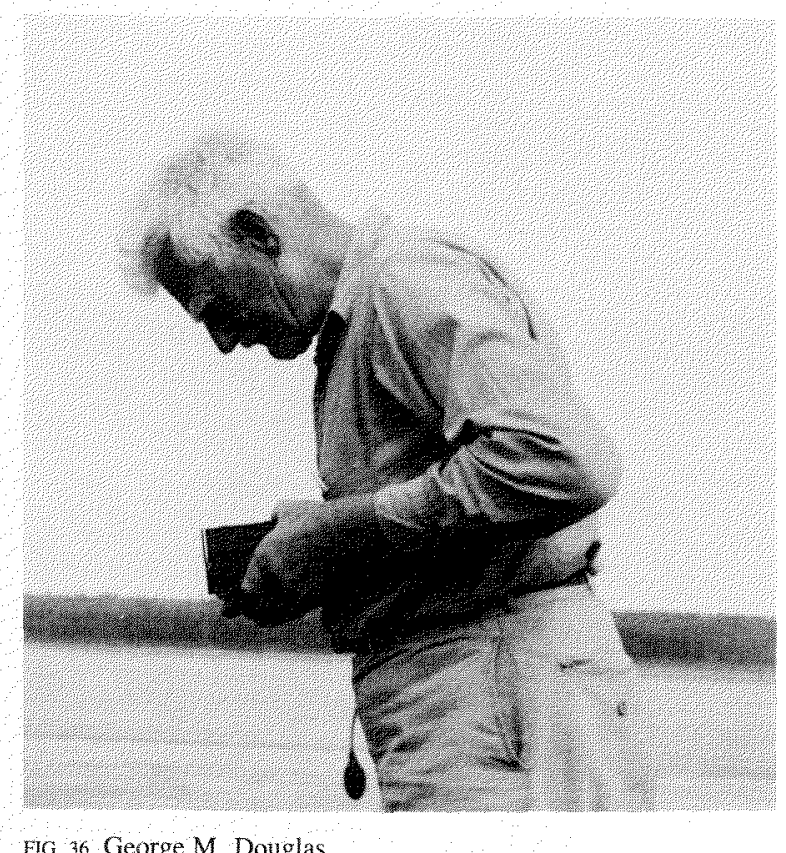


gov't control. Whole works admittedly speculative. No building or fire hazard regulations. No N.W.T. codes applicable to situation. Vic Ingraham (Speed disaster at Bear Lake) runs the Yellowknife Hotel and is unofficial bootlegger $-\$ 10$ a bottle. Douglas says [David] Hanbury [author of Sport and Travel in the Northland of Canada (1904)] was so painstakingly conservative as to very frequently underestimate distance. Holds out [Guy H.] Blanchet [of the Topographical Survey of Canada] very highly. Spoke with a gleam of savour in his eye of both the Hare River \& Lac la Martre ventures. Spoke of two chaps starting a private school in the Seigneury Club area - check on this. So warm; a "tropical" contrast. In here at Resolution I was greeted by some of the boys on the Brown Construction job the chaps building the new radio station - but I had so forgotten all about them that I didn't recognise them. A comment from G.M.D. on the Con. - a typical money job in that though the various "brains" have everything of convenience, there are no adequate docks, derricks, unloading, handling of freight, or storage facilities - a "cream puff"' job. As we approached the south shore the water was covered with the greenish-yellow pollen of the spruces. Sometime after 2 a.m. it began to blow and we moved off behind some islands and anchored. They say the eastern channels of the delta - like the Nagle - are blocked up. [Dr. J.H.] Riopel is the Indian Agent here now after the Amisk [Lake?] row.

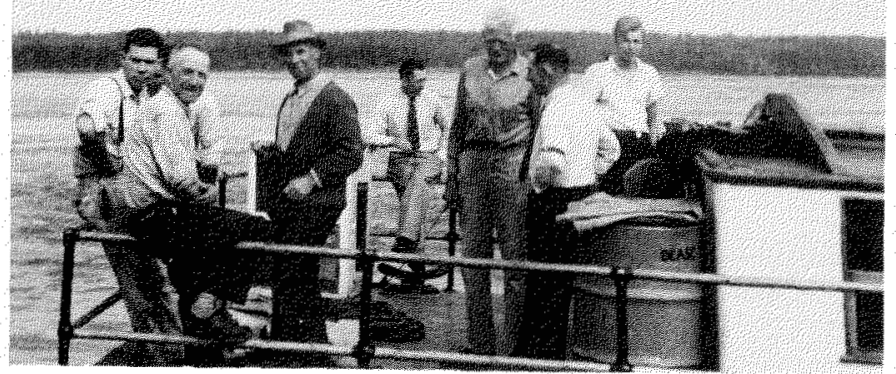

Fo. 37. Douglas - "a very tall gentleman

\section{September 2nd}

Clear, wind NW. Blowing, so we lay behind the island until well into the early afternoon. We rolled and pitched so last night, and the timbers made such a racket screeching and groaning - not to mention the empty oil drums which rolled and clanged about - that we had little sleep, and so we slept in until noon. The cook is a most generous fellow; he gave us a bowl of soup which tasted fine. Later the two barges were put on tow as we crossed to the opening of the channel. Our barge was the tail one, so we were quite exiled all afternoon. However, it was very pleasant and we did not roll and pitch anything like the other barge or, particularly, the Dease Lake. We made the flag buoy late in the afternoon and shifted the barges from tow to push, so John's and my period of exile was over. It was fine and warm on the placid waters of the Slave. Douglas indicated various channels as we progressed upstream. Both the Nagle and Jean Marie are almost blind openings coming downstream unless one is on the alert. The Nagle is particularly small and swings back behind an alluvial cutbank. We got in to the sawmill about nine and my good travelling companion John Paulson got off to work there this winter. They decided to leave a barge here, so the night was made hideous with the clang of the empty steel drums being shifted into this barge and with the roar and rattle of the hoist. The barge got so filled with drums that I was forced to move out and took up quarters on the roof. For a long time I watched a brilliant display of the Aurora. Very spiral-nebulae in effect, twisting \& untwisting and with a sheath of light which seemed to shift like blown smoke. I played a game of chess with $D$. and lost. He carries a small pocket set with him and works out chess problems. We scared up a small flock of geese on a mud flat at sunset and they went swinging away - already the geese are moving south. A gorgeous sunset. Sorry to see John Paulson leave. He has been an excellent, generous, good-hearted companion.

\section{September 3rd}

Bright \& fair. A marvellous day. Light westerly breeze. Slept until late on the roof of the barge. In the afternoon played chess with $\mathrm{D}$. and won one game, lost two; he is a deliberate, careful player. Later we talked a bit on many things. It developed, to my surprise, that contrary to the book [Waldron, 1931], Hornby was no monk. When Douglas was at Dease Bay Hornby was living with the woman now D'Arcy Arden's wife. [For as accurate details as we shall ever have concerning Douglas's association with Hornby and other points about Hornby raised by Downes, see Whalley, 1962.] On his trip down the year he was to winter with [J.C.] Critchell-Bullock, he came down the Peace with [Malcolm] Stewart \& [Matt] Murphy, the trappers who saved Bullock and Hornby that year [1924-25], and wrote $D$. a long, doleful letter about how he was sick of the North (because of an affair with a girl in Edmonton [Olwen Nowell]). Hornby \& Bullock never hit it off at all. Bullock's diary was read by Douglas and is full of invective against Hornby. However, Hornby never said a word against Bullock outside. D. thinks that after the war H's eccentricities were definitely on the decline. Douglas and Boblett, a friend and intimate of Hornby's, were at Snowdrift some time back and [Helge] Ingstad was there also (the year he went in with the Caribou Eaters [1928]). D. \& B. were talking of Hornby and the book he had planned to write (at one time all of Hornby's notes were left with Douglas). Douglas thought Ingstad was some sort of anthropologist. But anyway, there he was, drinking it all in, and of course stole the title outright for his own book [Land of Feast and Famine, 1933]. When one reads Ingstad's book one is again and again reminded of his huge size attention is drawn by him to this repeatedly. Actually, says Douglas, and oddly enough, he was a small man about my size $\left[5^{\prime} 7^{\prime \prime}\right]$, and smaller than the band he was with, which was a group of big men. That band is almost dead to a man today from the "flu." Douglas's views are very refreshing - frank and extremely humorous. The story of Hornby, D'Arcy Arden and "What the hell are you doing with my wife?" is an excellent one. Again and again as we moved on up river we started up flocks of geese, which would rise and wheel away, honking and crying. Occasionally I saw a thin line of ducks hurrying south. Most of the birches are tinged with yellow. [Major L.T.] Burwash is not the discoverer of Yellowknife, nor is his mine producing a thing; as Douglas says, the North is an extraordinary place for money to be made without a thing actually coming out of the country. The fact remains that tremendous sums of money have been poured into mining ventures here by the investing public, \& to save its face the Con. had to find something or lose out. If precedent is followed, the values will 
not increase in depth in this northern area. The year H. \& Bullock went in they had a falling-out, and Hornby went down the Peace $R$. to avoid him. They hitched up somehow at Smith. D. says Hornby's brother was a proper son of a bitch. Hornby's mother died and left $£ 50,000$ to $\mathrm{H}$., which reverted to the brother and sister, as [Edgar] Christian's diary established his prior death. As I have observed elsewhere, the diary [Christian, 1937] was very poorly edited. No mention of [H.S.] Wilson \& his party at all. [Dr. Wilson and his three companions discovered the bodies of Hornby, Adlard, and Christian in a cabin on the Thelon River in June 1928: see Dewar, 1978.] Wilson started from Resolution and went right through, passing Douglas, who was also eastbound, by going through a series of lakes to Snowdrift. Douglas is a great one for camp gadgets and such. Designs his tents, sleeping bags, food bags. His grub supply numbers all manner of selected things such as hominy grits, Demerara sugar, various dehydrated vegetables, a special breed of hardtack, erbwurst, and such. D. was asked to write a life of Hornby at the height of the excitement but turned it down for lack of data. It is now $7 \mathrm{pm}$. There is a beauty and a peace at this time here which passes all human understanding. A golden sunset; the birches just touched with yellow; this broad silent river; the tall, straight, sombre spruces; the golden, golden light; somewhere a wild goose calling; the deepening purple of the horizon: one might well wait all summer for a day like this. Later: a beautiful clear night with aurora and many shooting stars. I lay for hours on my back watching the heavens. Every time I see a shooting star I send a message to someone. It was so warm I could not sleep, though toward morning I finally managed to drop off. Temp. $72^{\circ}$.

\section{September 4 th}

Bright \& fair, warm, slight breeze. We ran all last night and got in here to Fort Smith about $3 \mathrm{pm}$ [Fig. 38]. One could not ask for a more pleasant trip; cloudless skies, hot, brilliant sun, and excellent company. Douglas - I must remember the address: George M. Douglas, Lakefield, Ontario - is a most extraordinary man, active as a cricket, always on the move, and so keen. He told me of the first time he met Hornby. They were going downriver on the Distributor (?) [no: on the Mackenzie River, in 1911] and were having breakfast when Hornby and his companion, [Cosmo Dobrée] Melvill, an Englishman, adventurer, and big-game hunter, came aboard. Douglas says it was impossible to get Hornby to talk consecutively on anything. Melvill was very reserved, the typical British big-game hunter, but, says Douglas, Hornby was just like a monkey, and as he chattered he kept digging filthy fingers into the sugar bowl, much to the growing annoyance of the captain, Mills. Hornby never had any really concrete objective. His notes, such as they were, were absolutely incoherent and without sequence. Once he undertook the mission to write up something on the caribou, but it finally amounted to but a page and a half (typewritten) of material already well known. Hornby's mother told $D$. that he had been pointed for the diplomatic corps, had indeed had one job as aide of some sort, but receiving no further post turned to the North. With his faults, says D. - the impossibility of living with him - he had great qualities of extreme generosity and was a perfect gentleman. (Note: Jim Cornwall - Labyrinth Lake the Grease River route and the unknown headwaters of the Thelon.) In here now, I went up to see if I had any mail from

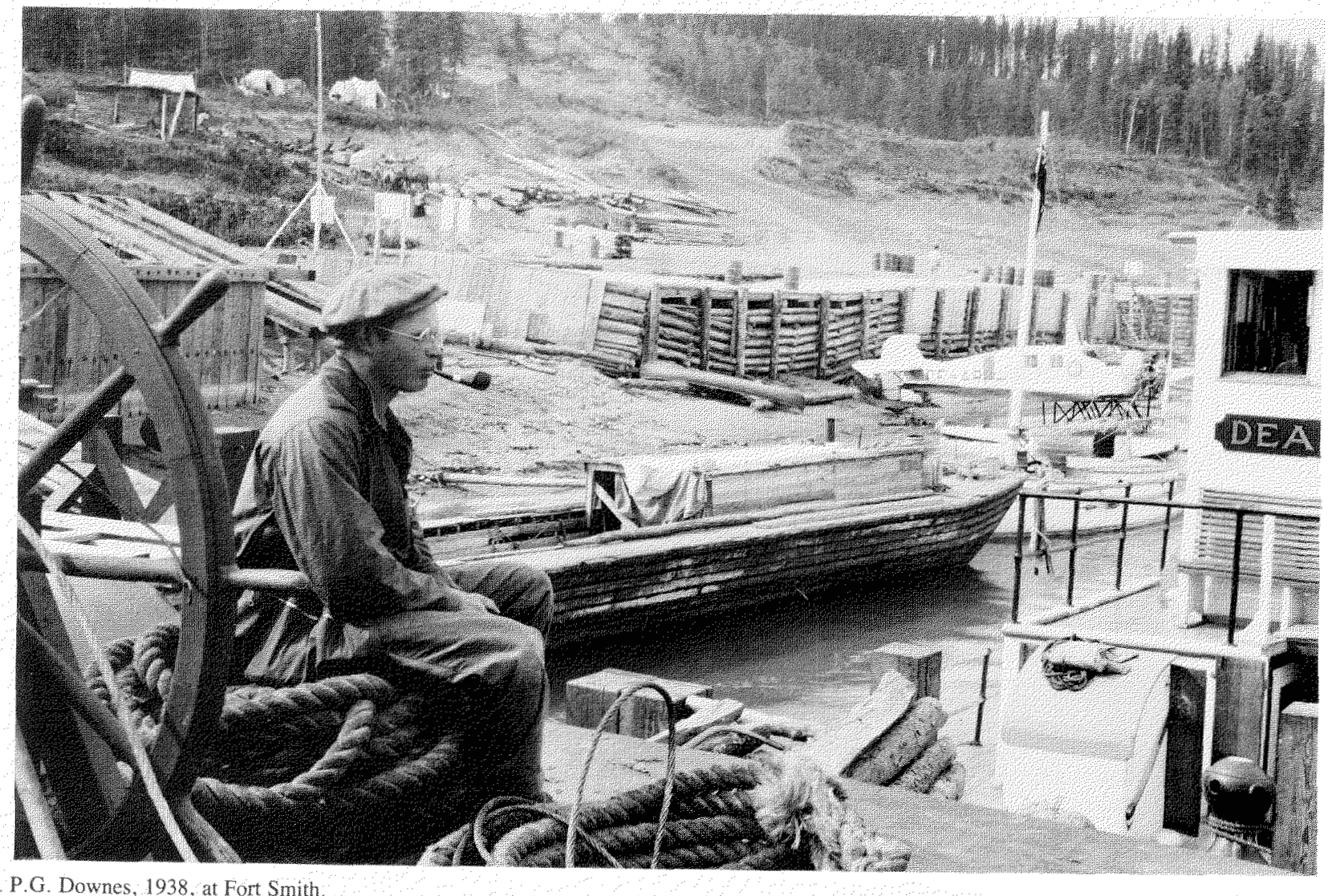

FiG. 38 P.G. Downes, 1938 at Fort Smith 
E.G., but there was nothing. I was bitterly disappointed, and cannot understand why none was ever sent. You imagine all sorts of things. It is particularly upsetting when one is on the way back after the long trail, and particularly too, after the tenor of the letters on the outside; disappointments of nature are enough, without the complicating human element. One rather amusing thing re the mail. When I left Prince Albert, Keith [HBC] sent my clothes to the District Office at Edmonton. The Edmonton office of course did not know me. They, with usual thoroughness, sent word up north to notify me that a "brown zipper-bag bearing the name P.G. Downes, Belmont Hill School, Belmont, Mass." was in their office. Meanwhile, I had left in Sequoizi, while they assumed I was on the Distributor. Here at Fort Smith I slipped through unknown and went down on the Radium King, of course - an entirely different outfit. The question all summer has been, where was P.G. Downes and how to get hold of him - further, what to do about the mysterious brown zipper bag. To the HBC I had disappeared off the face of the Globe. All this I discovered when I went in to the Transport Office to see about mail. Douglas, who was at one time a great pistol \& rifle enthusiast, approves highly of the Mannlicher 6.5 for the Barrens. A variety of trips presents possibilities for another year. The names of the chaps starting the school [Sedbergh School, Montebello, P.Q.] are Messrs [Frank] Duxbury \& [Tom] Wood. Both are northern travellers, Duxbury having done the Porcupine-Yukon route, Upper Finlay, and Albany. These chaps might prove of value sometime. Here is all the damnable vagueness about boats. Theoretically, the Beaver Lake should leave Fitzgerald tomorrow, but no one knows where she is. If I do not get off tomorrow I will be put back a whole week and be late. This I shall not countenance, to the extent of paying $\$ 65$ and flying to Edmonton. I am particularly determined to get to Milwaukee and find out what the situation is. We stopped at Bell Rock to take on some stove wood. Bell Rock, named after Doctor [Robert] Bell [G.S.C.], is one of the few exposures (3) of Devonian limestone on this lower river; there is no other exposed rock over the whole course. The rapids here are caused by granite ledges. I chatted with a fellow in a scow bound for Reliance to trade. He was forced to jettison $500 \mathrm{lbs}$ of flour owing to low water and wind at the delta of the Athabaska. Here is an example of the extraordinary spry activity of $D$. We stopped at the mouth of the Slave to take on stove wood. The crew, of course, undertook this task; when up the narrow board walk slowly comes D. lugging a huge log on his shoulder. An amazing old gentleman, and absolutely no one's fool. Still no word on the Beaver Lake, which is assumed to have hung itself up on some sand bar (it has not reached Chipewyan). Later went calling with Mr. Douglas. We were going to the Conibears', but detoured to visit Billy Cook, an old timer who used to be at Norman and now runs a store here. Chatted for hours, particularly on the MacAlpine affair and the heroic part played by Geoffrey [no: Walter] Gilbert. [In September 1929 Col. C.D.H. MacAlpine and his Dominion Explorers party were lost when their aircraft went down near Dease Point. The aerial search that followed was the most famous of the pre-war years. MacAlpine and his group survived. See Blanchet, 1930.] Douglas said one thing which stuck in my mind because of its concurrence with my own view. He had been at Reliance when the trappers were going in to their camps. There is a small group who all pool in and charter the big Bellanca to fly in. Said Douglas: "The real aristocracy of the North, the only ones who really bring something out of the country." Millions have been spent on mining, but a gold brick has yet to be brought out. For 10-12 years now, the money has been poured in, with nothing coming out except profit on speculation. Steffanie [sic] is, according to these two competent judges, an extraordinary man. One year he went in with 50 $\mathrm{lbs}$ of flour, $3 \mathrm{lbs}$ of hardtack, a pound of tea, and plenty of ammunition. The flour was used by being scattered from the plane to see which way the wind was blowing; the next spring the hardtack was eaten, but he still had the tea. He is the chap I talked with at Yellowknife. It was from him that Matt Berry got the most accurate and productive hypothesis as to the location of the MacAlpine party. Later I went back to the boat to get my outfit and make a camp. As I went down from the dock I saw an Indian girl - so dark I could not distinguish well - but I looked, and she said, "Oh, are you back again so soon?" I could not for the life of me recall who she was. I went back after making my camp to find her, but she was gone. Camped in the same spot in the spruce overlooking the water. The river is extremely low and rocks are exposed far below the rapids right in line with my camp. Some important information: for lone travelling, D. says [fish] net $35^{\prime}, 41^{\prime \prime}{ }^{\prime \prime}$ mesh. Also, Indian method of floats is superior, as the net does not tangle so badly. I examined some floats, and they use wedges, or at least pieces of wood which bob up vertically and are tied by a short line to the net. Furthermore, stones or leads attached by lines are much superior.

\section{September 5 th}

Clear. Bright \& Fair. A day of great annoyance. Theoretically, and expectantly, I was scheduled to go over to Fitz. and take the Beaver Lake back to Waterways. Along with two carpenters from Vancouver I waited impatiently all forenoon for word of the boat's arrival. Getting word, I packed up (rolled my sleeping robe) and got ready to go over. At the last minute I was informed that no passengers were allowed on the boat (she is strictly freight). This unusual edict simply spoils my chances entirely. I argued in vain. They were very prim and prissy here, and I could not get over to Fitz. to see them over there. So here I am. It looks as if I will be forced to fly out, for no boats are due in for some time, the end of the week at least, and this would make me far too late. I was quite annoyed and upset about the whole matter. However, there seemed nothing I could do about it. Examined Douglas's flotilla. He has two gigantic canoes, $20^{\prime}-21^{\prime}$ Peterboroughs. Really enormous affairs. Two smaller, varnished canoes, one $16^{\prime}$ basswood, one $15^{\prime}$ cedar \& canvas. All of them are in beautiful shape, glistening and unmarred. He is shipping out the two wooden ones. He has a great store of miscellaneous foodstuffs, etc. stored in the HBC warehouse. What an amazing man. What vitality. All the wrangling and what-not about the boat took up most of the day. Finally, in disgust and high dudgeon I grabbed my stuff and went down the river a piece and made a camp. Later I went up to visit the Conibears and had a pleasant time. Coming back, I ran into Douglas, who was out walking. We repaired to the porch of the hotel and passed a pleasant hour chatting. Several interesting facts developed. My map of Dease Arm (Great Bear Lake sheet) shows no major islands; other editions show a very large island. It appears that this "island" was on the [aerial] photo plates. D. was sure there was no island there and informed them of such in Ottawa. Examination of the plates established that there was something, and though the pictures were made well on in 
August, the "island" was in fact a large field of floating ice. Later a flight by D. over Dease Arm established conclusively the fact that there was no island there. Curiously enough, Jack Raymond, who wintered at Caribou Point, claimed to me that there was an island there. ["The Great Bear Lake country is for the most part still unknown, unexplored, and unmapped. The lake itself, though one of the great fresh water lakes of the world, has not been fully delineated; the northwestern arm has not even been penetrated to its full limits"' (Camsell, 1937).] Douglas says he certainly would have liked to have more excerpts from Bullock's diary. Apparently it was not until reaching the portage [Pike's Portage from McLeod Bay, Great Slave Lake to Artillery Lake, September 1924] that Bullock realised what he was in for, as up to that time they had been travelling with trappers. There he began to run into a few of H's eccentricities - and the latter's refusal to take or have various things [Bullock's scientific gear] taken over the portage. Outstanding error in Ingstad's job is the quite erroneous geographical and directional data. He insists on talking of travelling north (for in a book on the north one must always be travelling north), where in reality he was travelling southwest. This is obvious if one checks his locations on the map. The meeting with Douglas has certainly been the high point of the return and an extraordinary break of fortune for me. Retired to my bower and was considerably occupied by mice or a mouse. First the mouse, one of the microtas probably, ran across the top of my sleeping robe to my chest, then jumped off in surprise when I shook in protest. Then he attacked the grub bag. Not getting anywhere, he or she suddenly jumped onto my head, much to the surprise of both of us. This last act was his or her final act of the evening. I wish I had kept some record of my dreams; lately they have been most unusual and revert back to people of so many years ago.

\section{September 6th}

Bright \& fair in a.m. Up and about at a reasonable hour. Curious fact of these regions: the Indians differentiate between a "white man" and a Frenchman, always distinguishing the two. For instance, a chap was trapping on Hay River and the Indians at Resolution were asked by someone, "Was he a whiteman?". "No, not a whiteman, a Frenchman." I talked for hours this morning with a very old man who, amazing to say, turned out to be Old King Beaulieu of Resolution [Fig. 39]. [His grandfather, Francois Beaulieux, was one of the voyageurs who accom-

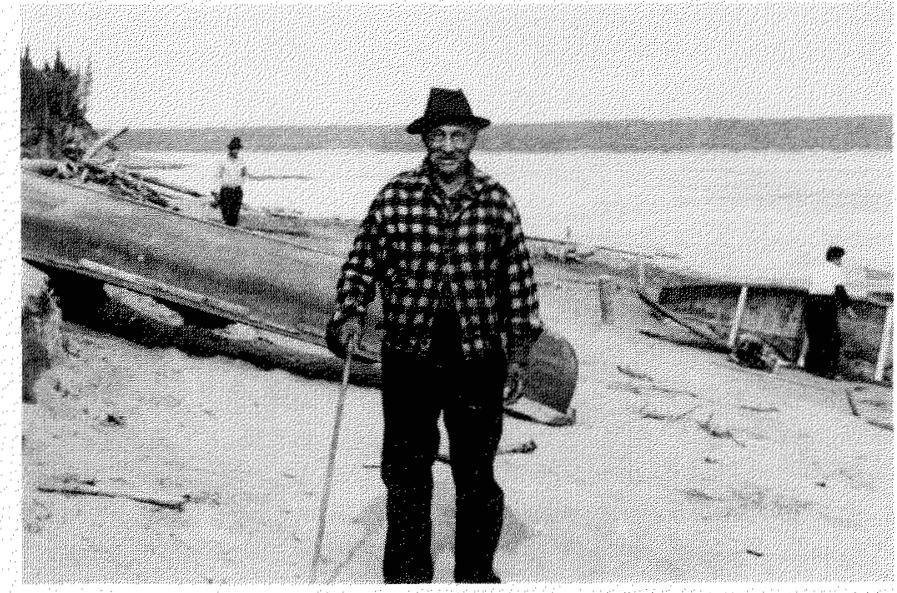

FIG. 39. Paul "King" Beaulieu. panied Alexander Mackenzie on his voyage across the Rocky Mountains to the Pacific in 1793. In 1820, when a North West Company interpreter at Fort Chipewyan, he provided John Franklin with "some satisfactory information which we afterwards found tolerably correct, respecting the mode of reaching the Copper-Mine River. . . . He sketched on the floor a representation of the river, and a line of coast according to his idea of it" (Franklin, 1924).] He took great pains to tell me he is 84 years old and has had 19 children. He speaks an extremely garbled English, though he tells me he is fluent in Dogrib, Chipewyan, Cree, Slavey, Yellowknife. He says he cannot speak Loucheaux or Husky. I shall deal with him anon. As Old King - or, as his name really is, Paul "King" Beaulieu - and I were talking, Douglas paddled down in his canoe. This was a striking picture - the bright, varnished canoe and the erect, white-haired Douglas. King wanted to know his age, which is 61 years. Afterward King said to me, "He is just a boy." D. invited me down to his old camp where he was going in order to do some washing. He paddled down, and I went up to the Post Office to mail off Volume III of the summer's diaries. I do hope Mr. Rand has received the other two all right and has them stored in a safe place. I worry more about my diaries than anything else. With the years they will become increasingly precious. They are packed with small details interesting to no one, I suppose, except myself. After this I walked down along the shore for about two miles to D's camp [Fig. 40]. This was an interesting walk. The shore is covered with driftwood; it is

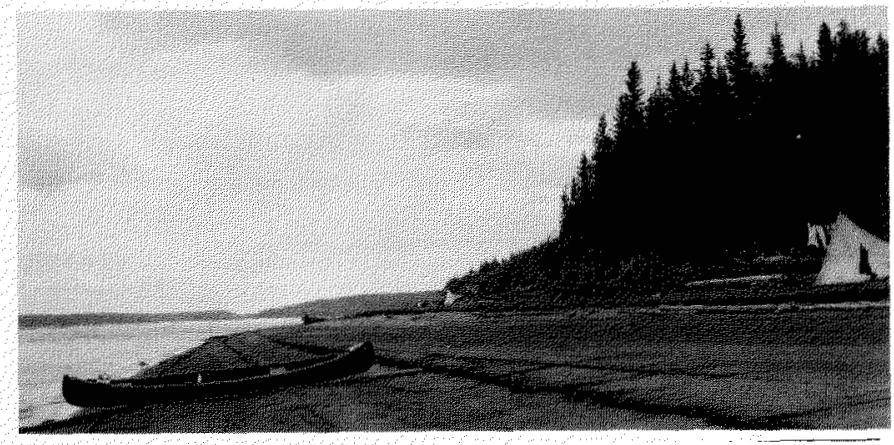

FIG. 40. George Douglas's camp below Fort Smith.

frequently clay which, packed and bedded, projects out into the river from beneath the sand, and these tongues of clay are beds for the most perfect specimens of concretions I have ever seen - hundreds and hundreds of them; they are mostly of a flat-bottomed knob-like form. I had a nice lunch with Douglas and then we paddled up again. He handles the canoe very skilfully. Later he went up on the hill to dry his clothes. He is remarkably clean and neat and puts me and my Indian habits to shame. Back to Paul "King"' Beaulieu. It was very difficult to get what he said except when his son interpreted for him. He said that the trouble with the doctors today is that the medicine they use is too old. In the old days the medicine men would go out and get fresh medicine each summer. Now they leave it in bottles and it loses its power. He said that in the old days when a man had something wrong with a particular part of his body, the "doctor" (medicine man) would treat that part to cure it. He would bleed (he described the quartz flake lancet on a stick) that part where the pain was and cure it. Now, he says, You have a pain in the chest, in the head, anywhere - the doctor gives you something to put, not on the pain, but in your mouth, and you 
"have lots shits" which "is no good, only make you weak." He says when they rowed down river [in the 1880s] with Bishop [William C.] Bompas (whom he commends highly) they never worked on Sunday - because Jesus said to work only six days. The road here (a government job) collapsed because they worked all the time on it and Jesus did not like it. He says [Warburton] Pike was a bad one - a liar. He says Pike claimed he shot the five musk-oxen when actually it was the Indians who did. [See Pike's The Barren Ground of Northern Canada (1892/1917). Pike had reciprocated Paul's dislike: "It was now that I made the acquaintance of King Beaulieu's sons, Francois, José [Sousi], and Paul, each of them married and father of such a big family that it makes one tremble for the future of the Great Slave Lake country when the next generation has grown up. . . . In character a Beaulieu [exhibits] a sort of low cunning more like that of an animal than a human being.

The only way to treat him is as you would treat a dog; if you are kind to him he takes it as a sign that you are afraid of him, and acts accordingly." George Simpson might have concurred: some seventy years earlier, in his Athabaska journal, he implicated Paul's grandfather (one of the N.W. Co. "Bullies" who caused him so much trouble at Fort Wedderburn during the winter of 1820-21) in a murder plot (see Rich, 1938). Ernest Thompson Seton, who travelled with two of Paul's brothers, Francois and Sousi, in the Great Slave country in 1907, was moved to exclaim, "Oh, why did I not heed Pike's warning to shun all Beaulieus; they rarely fail to breed trouble" (Seton, 1911). The family traits seem not to have diminished noticeably with age. When Sousi, by then an old man, accompanied Guy Blanchet on his survey of the headwaters of the Coppermine and Back rivers in 1923, Blanchet detected "a certain truculence" in his behaviour (Blanchet, 1964).] Paul made the observation that his grandfather, the original Beaulieu, had 7 wives until he travelled far south and met the priest at Portage La Loche, who told him it was wrong, that Jesus did not approve, and that he should give them all up for Jesus except one. He said his grandfather gave up all of them except the oldest one, who had no teeth, for, said King, his grandfather did not think Jesus would want an old woman without teeth. Beaulieu observed that his grandfather having seven women, his father having many halfbreeds, and he himself having nineteen halfbreeds (from 3 wives), the Beaulieus had filled the country with halfbreeds to work for the Hudson's Bay Company, yet he could not get one cent of debt from the Company. He says the priest and the Bishop are bad because they say Jesus was a poor man, yet they are always asking for money, money, money for him. He says they travelled 67 days for muskox one time. Says they got 15 \& had to pack the bones as well as the skins, for which he got the equivalent of $25 \notin$ a skin. (Was this for Pike? - although paid for it by the HBC?) [See Pike, 1917:121, 139, 147.] He described a sort of muskox pound for me along these lines: When a muskox was sighted, men would take up positions and set up stones with a shirt or bit of clothing on them, and at the end of the corridor would be a small lake into which they would drive the animal. Once in the lake, they would not let it get to shore, and eventually it would drown. I could not make out one part of the recital - something about one man who would call or direct the muskox. (Among the Dogribs it was a common belief that these animals understood an Indian's language.) [Among the Yellowknives, too: see Pike, 1917:183-184.] On the Pike expedition [1889] he was accompanied by his brother [sic] Manville and 4 Indians. [Mosie Mandeville was the brother of
Michael Mandeville, the interpreter at Fort Resolution; Pike admired him as a canoeman. Presumably, these brothers were descended from Francois Mandeville, who served the HBC as an interpreter from 1818 to 1820 at Great Slave Lake and in the Athabaska district (see Rich, 1938:113). Pike, a hardbitten, idiosyncratic Englishman, was known as "Dirty Pike" by his closest acquaintances (McTavish, 1963).] The old gentleman called on me again in the evening. He was in a great rage against the world in general and his wife in particular, who wishes to stay at Smith while he wishes and intends to go to Rocher River. $\mathrm{He}$ is also very much in a religious fervor. He says that at Smith "The Devil is the boss; in the bush, Jesus the boss." The old man is most remarkable, considering the misadventures he must have had. One finger on his right hand is twisted almost in reverse from being caught in a flywheel. One wrist has been broken and is badly misshapen. He was shot through the groin, yet he gets about in good shape with the aid of a cane. He wears spectacles. He went to great pains to explain that the name "King" was bestowed by the Queen on his father (who went to England?), who also received a medal. [One doubts that King Beaulieu visited England, let alone his Queen. The medal would almost certainly have been one of those awarded by the HBC for loyal service.] There was also some incoherent business about someone being lost and his father travelling all over to look for him (Franklin?). It was late when he finally scrambled off and I turned in. More dreams, and still earlier premonitions in my life.

\section{September 7 th}

Very clear, wind strong easterly, cold - like a fall day. Douglas has the most complete outfit one could imagine. He is an authority on and connoisseur of camping outfits. He has a set of copper kettles he obtained some years ago at one of the old posts. They are quite superior because of their high degree of heat conductivity. The Indians at Rae were all kicking that they could no longer get copper kettles, which melt snow so much faster. D. says his idea of the perfect kettle would be one of solid silver - high conductivity, no rust, no danger of the tin melting off, infinite wear. Douglas unpacking, packing various maps, photographs, etc. He has a bewildering array of maps, plans, aerial photographs; knapsacks, haversacks, packsacks, sacks. He told me Charles Camsell (I forget just what his official position is - one of the big bugs on the N.W.T. CommissionHead of Dept. of Mines \& Resources?) [Deputy Minister] was in town and that he had spoken to him on my wanderings. Later Camsell himself came down to fly south in his C.A. charter plane, and D. introduced me with: "Dr. Camsell, I wish to introduce Mr. Downes; he knows more of the history of the north country than J.B. himself." (J.B. Tyrrell) Incidentally, J.B. is in the North for the first time since his last trip of 1894 . Dr. Camsell told me he studied physiography under [W.M.] Davis \& [Isiah] Bowman at Harvard. He suggested that I drop in to see him when I come to Ottawa. The Camsells are an interesting lot and intimately bound with the Mackenzie District. The old Camsell [Julian Stewart] was Chief Factor at Simpson and married an Indian woman. Dr. Camsell is the son who turned out most successfully - there are brothers at Resolution and Rae. The old man, from accounts, was an autocrat of the old order. When the Indians brought in their fur at Christmas \& Easter, so the tale goes, he sat on a sort of pedestal and each Indian deposited his bundle of fur before him. No price 
was asked or given. He approved the catch by silence, and disapproved in no uncertain terms. Eventually I went up to the HBC to buy a pound of hardtack and to telephone [A.A.] Holliday at Fitz. not to sell my canoe. He says Sid Porter has a deal on with a guy at Yellowknife, but I told him to call it off unless he had committed himself. To anyone interested in camp menus: since the day of my arrival at Yellowknife I have been living on straight hardtack and tea, with occasional jam. A one lb. can of jam costs $40 \%$. The dialogue between Old King Beaulieau (he pulled out today) and Douglas was most amusing. Said D. to B. (indicating me), "This fellow is a great traveller. $\mathrm{He}$ is like Diogenes, who travelled only with a cup and who, when he saw a man drinking from a river, threw away the cup." The Old King looked rather mystified, but grinned a snaggletoothed grin anyway. Well, my days of the North for 1938 are almost over. While this extraordinary fine weather lasts I cannot bear to leave - but the geese are moving on and so must I. I truly dread the long train ride. Someday, if I should ever have a son, or if someone should ever read these pages, I suppose they would be struck by a vein of conceit - but it is a curious thing, and one needs to experience this type of wandering to understand it. One needs it in the face of the world about him. It does him good. Hornby, after reading D.'s book, Lands Forlorn, allowed that it was a pretty good account but that $\mathrm{D}$. had made one grave mistake. Where D. had said he had packed in $120 \mathrm{lbs}$ of meat, D. was wrong, for he (Hornby) had packed in $220 \mathrm{lbs!}$ This is an exaggerated case of something one feels very intimately [see Whalley, 1962:331]. I have been happy as a bird in my little camp here. For just these few short days the North has been at its very best - clear, warm, no flies. Someday, shackled down somewhere, how I will think longingly of this little camp on the Slave at the 60th parallel [Fig. 41]. The fishing is becoming good, with conies, jacks, and whitefish daily in the nets off the little points below my camp.

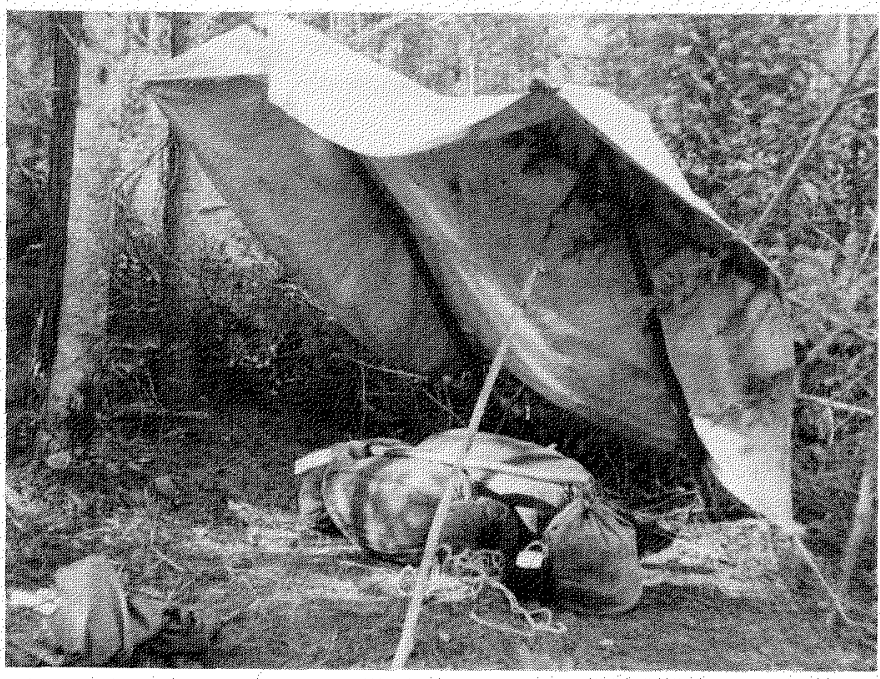

FIG. 41. "Last camp - 1938."

\section{September 8 th}

Overcast, wind E. Appropriately enough, this entry, and I expect it to be my last in the Northwest Territories this year, is made in the firelight of what I expect is my last camp. I have every expectation of flying out tomorrow - the summer of 1938 is over. I roamed around all day, but mostly spent my time right here in my camp. It has been very grey and overcast, and I expect the brief loveliness of the last of summer is over. The birches are all yellow, and here and there are bright bits of red foliage of some bush or other. Douglas is packing too. He says Blanchet and I would hit it off fine, the way we both travel. He says January is a good time to visit him. Both he and his wife [Frances] are very fond of skating. What a remarkable, fine man he is! Late in the afternoon the one-legged Indian lad I have seen hopping about with a single crutch dropped in on me and I shared the last of my grub with him. Then we paddled across the river to his net - one large "cony" (inconnu), the first of that species I have seen - and visited his family. We had a supper of excellent dried moose meat. They have a tipi put up, the first I have seen in this country. It was a fitting farewell to my stay in the North. After this we took down his own tent, gathered up his dogs, piled them into the canoe, and paddled back across the river in the darkness amidst the rocks at the foot of the rapids. I intend to pull out tomorrow. I shall stop over at McMurray to see if I can buy a pair of white caribou moccasins I saw there. E.G. said that is what she would like, and though I have scoured the North I cannot find any. However, I remember a pair a trader had at Waterways, so I shall see if I can pick them up. If nothing happens to alter my plans, it is away to the south, then, tomorrow. I have one brown book left, cached at Edmonton, and may use that for a general summary. The firelight is flickering out. The south wind is in the trees and all that can be heard is the thundering roar of the "Rapids of the Drowned."

\section{September 9 th}

[Downes made topographical and geographical notes of what he could see below during the flight.] Reflections at McMurray (we can go no further because of bad weather to the south). This summer like no other has passed like a dream. Back here in civilisation I cannot believe that it is all over, that it was all over when I stepped into the plane at Smith. Last year I tried to make adjustments, to center my living outside. But I know now it is no use. This is my life - the wandering and tough living of the north country. I ask for no understanding, no companion, no reason. I hope I do a good job at school and earn enough to get back soon. I do not fit.

\section{September 10th}

Overcast, variable southerly winds. A day of great annoyance and indecision. No one seemed to be able to make up their minds about the weather. I sat around restlessly for hours waiting to be notified and at length was. Halker did not send over the white caribou slippers as he had promised me he would, so I could not get them for E.G. I went down to the M.A.S. dock and squatted there, waiting. Ran into Eric, the carpenter who sold me "Sequoizi." He said it was built by a chap at Chipewyan. The Canadian Airways fellows flew off. Stan McMillan brought in the Beechcraft, a very fast-looking, trig little job. At length, $\mathrm{Al}$ Brown, our pilot, had orders to go north, and Archie Van Hec brought in the big Bellanca - "Radium Express" from Edmonton. We all piled into this, eight of us, as our number had been augmented by Goldfields arrivals. We finally were up and away about 2 p.m. The windows were very dirty, so it was difficult to see much or get any pictures. Over the prairie - marvellous carpet of squares \& quadrangles and unbelievably straight roads. Country approaching Edmonton more forested and irregular. Landed at Cooking Lake. As we landed, thousands of ducks rose and fled before us. I am "outside." It is all pretty unreal sudden, and I feel as if I am in a dream. As I rode into Edmonton 
(23 miles) from the Air Base, I had a deep feeling of sadness and a longing to go back. Other years I haven't minded coming out and looked forward to it, wanted love \& a flagon - but I have not the slightest wish that way - only a wish to go back again. Soon we were in Edmonton, and I rescued my clothes. I went to the King Edward Hotel, and now $I$ have a ticket in my pocket which has "Boston" stamped on one end.

\section{SEQUEL}

Preserved between the pages of Downes's journal is the following piece of correspondence: "Fort Norman Wells, N.W.T. August 8th/39. Mr. P.G. Downes, Kind sir I'm sorry I did'nt have any time to answer to your lovely letter. but now I have a couple hours to write to all my friends I'll give you the first answer to thy kind letter. you ask me about the Hottah Lake country Behold the news about it, it was sure a lovely trip, the most I enjoyed was salling on that Lake going threw the Rocky hills for three days and half. the summer travelling in that country is sure lovely, try to come back sometimes again. good night good Luck From Mâlo A. Beueulé."

On the day Mâlo wrote, Downes was waiting to be rescued from South Knife Lake, Manitoba, where the plane in which he was flying from Windy Lake, N.W.T., to Churchill had landed after the pilot became lost and ran out of fuel. Downes never returned to the Great Bear country. In the years that followed, he and George Douglas became close friends. They corresponded regularly - always about the North - until Downes's death in 1959.

\section{ACKNOWLEDGEMENTS}

I wish to thank both Fred Peet and Archie Hunter, with whom I corresponded before and after the publication of their books, for providing answers to questions, for verifying certain matters, and, above all, for sharing with me their recollections of the North as they knew it so many years ago. I am also grateful to Bob LeBlanc of The Pas for putting me in touch with the late Father A. Chamberland, who served with the Oblate Mission in the Ile à la Crosse country in the 1920s and '30s, and to Father Chamberland himself for a wealth of information about his fellow missionaries and for the photograph of Father Ducharme. I am especially indebted to Mrs. E.G. Downes for her generosity and her encouragement.

\section{BIBLIOGRAPHY}

ANONYMOUS. 1939. John Firth of Fort McPherson. The Beaver 270(3):48. BELL, J.M. 1931. Far Places. Toronto: Macmillan of Canada Ltd. 174 p.

BLANCHET, G.H. 1930. Searching the Arctic by aeroplane. Canadian Geographical Journal 1(8):641-662.

1964. Exploring with Sousi and Black Basile. The Beaver 295 (Autumn):34-41.

BRIGGS, G. 1939. Waterways. The Beaver 270(2):28-29.

BURPEE, L.J. 1935. Where rail and airway meet. Canadian Geographical Journal 10(5):239-245.

CAMSELL, C. 1937. Great Bear Lake: an exploration and its sequel. Canadian Geographical Journal 14(3):127-144.

1939. The Yellowknife mining district. Canadian Geographical Journal 18(6):311-315.

1954. Son of the North. Toronto: Ryerson Press. $244 \mathrm{p}$.

CHRISTIAN, E. 1938. Unflinching: A Diary of a Tragic Adventure. New York: Funk \& Wagnalis. 159 p.

COCKBURN, R.H. 1982. Prentice G. Downes (1909-1959). Arctic 35(3):448449.

1983. North of Reindeer: the 1940 trip journal of Prentice G. Downes.

The Beaver 313 (Spring):36-43.

1983. Prentice G. Downes's Eastern Arctic journal, 1936. Arctic 36(3):232-250.

1984. To Reindeer's far waters: P.G. Downes's journal of travels in northern Saskatchewan, 1936. Fram: The Journal of Polar Studies 1(1):130-176.
1984. Like Words of Fire: Lore of the Woodland Cree from the Joumals of P.G. Downes. The Beaver 315 (Winter):37-45.

DEWAR, K.M. 1978. I found the bodies of the Hornby party. Canadian Geographic 97(1):18-23.

DOWNES, P.G. 1943. Sleeping Island: the Story of One Man's Travels in the Great Barren Lands of the Canadian North. New York: Coward-McCann, Inc. $296 \mathrm{p}$.

1954. First Comers. In: Wilson, C., ed. North of $55^{\circ}$ : Canada from the 55th Parallel to the Pole. Toronto: Ryerson Press. 21-31.

DOUGLAS, G.M. 1914. Lands Forlorn: a Story of an Expedition to Heame's Coppermine River. New York: G.P. Putnam's Sons. 273 p.

ELLS, S.C. 1936. Portage La Loche. Canadian Geographical Journal 12(3):135142.

ENERGY, MINES AND RESOURCES. 1975. McLean River, Saskatchewan, 1:50,000,74C/11 Edition 1. Ottawa: Surveys and Mapping Branch.

FETHERSTONHAUGH, R.C. 1940. The Royal Canadian Mounted Police. New York: Garden City Publishing Co., Inc. 294 p.

FINNIE, R. 1936. Modern pioneering in Canada's western subarctic. Canadian Geographical Journal 13(5):241-255.

1942. Canada Moves North. New York: Macmillan Company. 227 p.

FRANKLIN, J. 1924. Narrative of a Journey to the Shores of the Polar Sea in the Years 1819-20-21-22. London: Everyman's Library. J.M. Dent \& Sons Ltd. 434 p. (Originally pub. 1823.)

GODSELL, P.H. 1934. Old trails to the arctic. Canadian Geographical Journal 8(4):151-162

HANBURY, D.T. 1904. Sport and Travel in the Northland of Canada. New York: Macmillan Co. 319 p.

HEMING, A. 1921., The Drama of the Forests. Toronto: Doubleday, Page \& Company. $324 \mathrm{p}$

HOARE, W.B. 1939. Sanctuary. The Beaver 270(1):38-41.

HUNTER, A. 1983. Northern Traders: Caribou Hair in the Stew. Victoria: Sono Nis Press. $151 \mathrm{p}$.

INGSTAD, H. 1933. Land of Feast and Famine. Toronto: Ryerson Press. 332 p. KEMP, H.S.M. 1956. Northern Trader. Toronto: Ryerson Press. 253 p.

KIDD, D.F. 1936. G.S.C. Memoir 187: Rae to Great Bear Lake, Mackenzie District, N.W.T. Ottawa. 44 p.

LAMB, W.K., ed. 1970. The Journals and Letters of Sir Alexander Mackenzie. Toronto: Macmillan of Canada. $551 \mathrm{p}$.

LAYTHA, E,M. 1938. Flying North for Radium. The Saturday Evening Post. 23 July 1938:18-19.

1939. North Again for Gold: Birth of Canada's Arctic Empire. New York: Frederick Stokes. 360 p.

MCTAVISH, G.S. 1963. Behind the Palisades: An Autobiography. Sidney, B.C.: Gray's Publishing Canada. 249 p.

OSGOOD, C. 1953. Winter. New York: W.W. Norton \& Co. 255 p.

PEET, F.J. 1983. Miners and Moonshiners: A Personal Account of Adventure and Survival in a Difficult Era. Victoria: Sono Nis Press. 203 p.

PETTY, H.N. 1939. Mackenzie River transport. The Beaver 269(4):48-50.

PIKE, W. 1917. The Barren Ground of Northern Canada. New York: E.P. Dutton \& Co. 334 p. (Originally pub. 1892.)

PRICE, R. 1967. Yellowknife. Toronto: Peter Martin Associates Ltd. 308 p.

RICH, E.E., ed. 1938. Simpson's Athabaska Journal. Toronto: The Champlain Society. $498 \mathrm{p}$.

ROBINSON, J.L. 1945. Water transportation in the Canadian northwest. Canadian Geographical Journal 31(5):236-256.

ROBINSON, M.J., and ROBINSON, J.L. 1946. Exploration and settlement of Mackenzie district, N.W.T. (Part I). Canadian Geographical Journal 32(6):246-255

1946. Exploration and settlement of Mackenzie district, N.W.T. (Part II). Canadian Geographical Journal 33(1):43-49.

SETON, E.T. 1911. The Arctic Prairies: a Canoe-Journey of 2000 Miles in Search of the Caribou; being the Account of a Voyage to the Region North of Aylmer Lake. New York: Charles Scribner's Sons. 415 p.

TWOMEY, A., and HERRICK, N. 1942. Needle to the North: the Story of an Expedition to Ungava and the Belcher Islands. Boston: Houghton Mifflin Co. $360 \mathrm{p}$.

TYRRELL, J.B. 1896. Report of the Doobaunt, Kazan and Ferguson Rivers and the North-West Coast of Hudson Bay. G.S.C. Annual Report (New Series). Vol. IX.

WALDRON, M. 1931. Snow Man: John Hornby in the Barren Lands. Boston: Houghton Mifflin. 292 p.

WATT, F.B. 1980. Great Bear: a Journey Remembered. Yellowknife: Outcrop Ltd. $231 \mathrm{p}$.

WHALLEY, G. 1962. The Legend of John Hornby. Toronto: Macmillan of Canada. 367 p. 1969. Notes on a legend. Queen's Quarterly 76(1):613-634. 